\title{
Short Study: Describing the Major Features of the Russian Battalion Tactical Group \\ Márk TAKÁCS ${ }^{1 \oplus}$
}

\begin{abstract}
Today we have clear evidence, that in Eastern Ukraine regular Russian forces have fought on the separatists' side. Based on open sources, the main type of unit deployed by the Russian Armed Forces is the Battalion Tactical Group. These Battalion Tactical Groups were deployed in almost all battles of the RussoUkraine war. In these battles, the Battalion Tactical Groups used the latest available Russian military equipment and they used them by the latest Russian manuals. It is very important to get familiar with the battle performance, the equipment and the tactics used by the Russian Battalion Tactical Groups in order to have a clear picture of the main tactical formation implemented by the Russians in Eastern Ukraine.
\end{abstract}

Keywords: tactics of motorised rifle units, activities in hybrid warfare, Russia, Ukraine, battalion, infantry, motorised rifle

\section{Introduction}

The Russian Battalion Tactical Group (BTG) is the main tactical formation used by Russia in the Eastern Ukrainian war. The Russian BTG is a modular tactical organisation created from a garrisoned Russian Army brigade to deploy combat power to conflict zones. It has been around since the Soviet times and is employed by not only the Ground Forces but also Airborne and Naval Infantry units.

The Russian BTG - although the name is almost the same as the NATO formation's name - is not equal with the NATO standard Battalion Battlegroup. In my study my goal is to describe the BTG, show its structure, its weapons used and how it conducts combat operations. The reason why I write about the BTG is that the Russian Federation deploys BTGs everywhere it takes part in an armed conflict (i.e. Georgia, Syria, Ukraine), so if NATO will face Russia in a future conflict, it is highly possible to meet with the Russian BTGs.

In this study, I will use the term "motorised rifle" instead of the term "mechanised infantry”, because the proper translation of the Russian expression is "motorised rifle".

University of Public Service, Assistant Professor; e-mail: Takacs.Mark@uni-nke.hu 


\section{Structure}

The BTG is created from a Russian Army Brigade. In order to understand the BTG, we have to take a look at the Brigade. The 2010 reform made the Russian Army transit to brigade from division. This reform (among other things) resulted in forming modular manoeuvre brigades of approximately 3,000-4,500 soldiers, each capable of conducting independent action and providing its own organic support. Each brigade is typically also a separated garrison. Serdyukov's reforms ${ }^{2}$ converted most of the force into independent brigades. The regimental/divisional structure is still common in the Russian Airborne (VDV), and there are still a few of the Ground Force Divisions, but the vast majority of Russian combat power is now found in independent brigades.

In terms of logistics, the difficulties of deploying and supporting a brigade is much easier than that of a division. Russia now has a much easier time projecting combat power by using smaller independent units. This is mainly due to the fact that the Russian Ground Forces make extensive use of rail transport, and smaller units are, of course, easier to transport. ${ }^{3}$

Russian manoeuvre brigades are composed of battalions, platoons and squads. Unlike U.S. brigades, which typically have only battalions reporting directly to the brigade commander, Russian brigade commanders may also have companies, platoons and squads reporting to them as well. Of course, these small directly attached subunits belong to combat support combat arms, such as electric warfare (EW), artillery observer (AO), CBRN, etc. These subunits are also important in the viewpoint of the BTGs because the BTG can receive some of these subunits, depending on the BTG's task.

In spite of being formed by a brigade, the very cornerstone of the BTG is a motorised rifle battalion. Battalions and below are considered "subunits" in the Russian system. Motorised rifle battalions have very similar structures, whether they are based on MT-LBs, BMPs or BTRs. However, battalions equipped with BTRs have an additional antitank unit because of the BTRs' less firepower. The battalion typically has three motorised rifle companies, a mortar battery (when deployed in conflict zones, the artillery battery is usually replaced by self-propelled or rocket artillery units up to the size of a battalion ${ }^{4}$ ), and reconnaissance, grenade launcher, antitank, signal, engineer and combat support platoons for a total of approximately 500 soldiers. If the battalion is acting independently, it is often organised to be a BTG. In this case, the battalion could have attachments including air defence missile, reconnaissance and logistical subunits as needed. ${ }^{5}$

The typical BTG that appeared in Eastern Ukraine has these attachments. ${ }^{6}$ But above these attached subunits, the BTGs received a tank company and sometimes a rocket artillery company in order to enhance the BTG’s firepower.

\footnotetext{
2 Dr Lester W Grau and Charles K Bartles, The Russian Way of War (Fort Leavenworth: Foreign Military Studies Office, 2016), 32.

3 Aleksey Ramm, 'The Ukraine Test: The New Image of Armed Forces Spoiled by French Kitchens', Voyenno Promyshlenny Kuryer, 29 April 2015.

$4 \quad$ Scott Boston and Dara Massicot, The Russian Way of Warfare (RAND Corporation, 2017), 10.

5 Grau and Bartles, The Russian Way of War, 35.

6 Nicholas J Fiore, 'Defeating the Russian Battalion Tactical Group’, 2017, 2.
} 


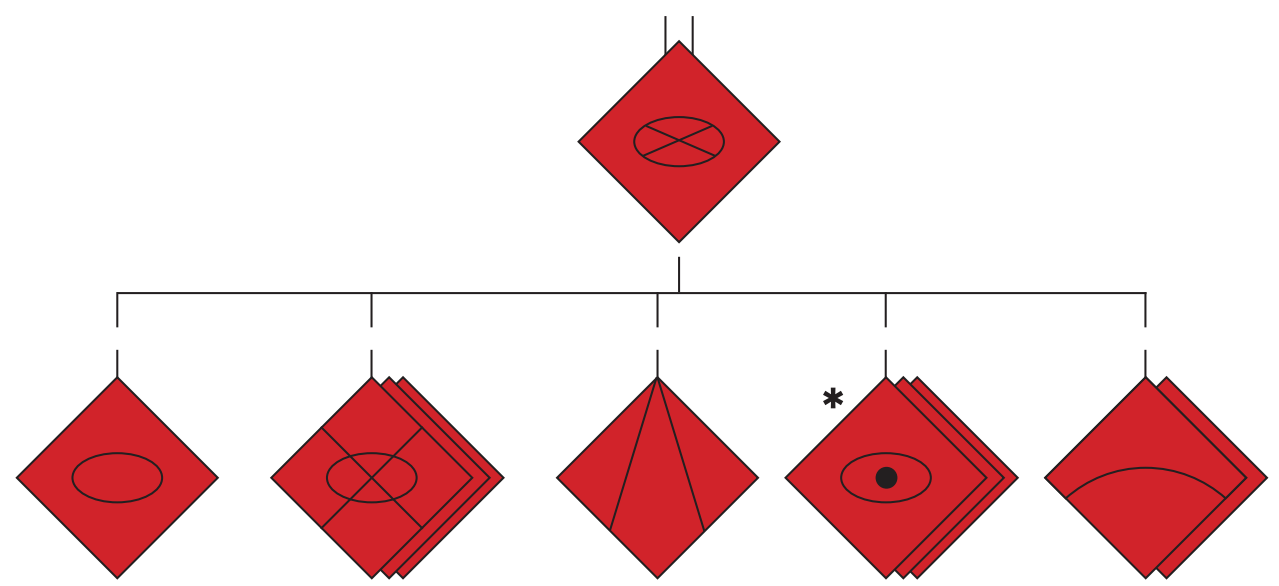

Figure 1: Schematic structure of a typical Russian BTG used in Eastern Ukraine

Source: Fiore, 'Defeating the Russian Battalion Tactical Group’, 2.

In the view of the personnel, the BTG perfectly illustrates the Russian Army's personnel composition in the middle of a reform. As many as a third of the deployed soldiers were high-quality contract (volunteer enlistment) soldiers who were recruited to be the noncommissioned officer corps of a modernised and professional Russian Army. They served primarily in the combat, EW and fires roles. The supporting units consisted primarily of lower-quality conscript soldiers.?

Captain Fiore in his article states, that the conscripts have a huge negative effect on the BTG's combat effectiveness: "This distinction is important: conscripts must be supervised continuously for even the simplest of tasks and are rarely used in combat." ${ }^{8}$ I do agree, deploying conscripts has a huge effect on the combat effectiveness of the BTG. But in my point of view, it is not a totally negative impact. The conscripts serve a limited time in the military, hence they can only be taught to conduct only one or two specific types of combat activities. But thanks to the limited types of combat activities, the conscripts can be trained to be masters of those one or two specific tasks. This "specialisation" of course makes the conscripts less versatile, but in case they are conducting a specific combat activity, which they are familiar with (i.e. convoy escort, attack in urban areas, etc.), they can achieve very high effectiveness.

Furthermore, using conscripts led by professional NCOs and officers harmonises with the Russian way of military decision-making (see sub-section Mission command and decision-making). 


\section{Technology and equipment}

Historically, local wars, and particularly proxy conflicts where one or more major powers are actively arming and supporting a belligerent, have often foreshadowed new technological developments that end up having a significant, at times decisive, role in subsequent major power conflicts. Ukraine is in fact a "proxy" conflict, but only in part. Soviet-era equipment is present in large numbers on both sides, while the Russians are actively introducing newly developed weapons systems from sniper rifles to advanced electronic countermeasure vehicles. ${ }^{9}$

The Motorised Rifle Troops is the largest of the Branch of Arms in the Ground Forces, providing the foundation of the Ground Forces. The epitome of the Motorised Rifle Troops is represented by the motorised rifle brigades with their high operational autonomy, versatility and firepower. They are able to conduct day/night combat under conventional and weapons of mass destruction conditions in different physical environments. ${ }^{10}$ This statement is very important because as I have already mentioned, the BTGs deployed in Eastern Ukraine are formed by motorised rifle brigades.

In general, these battalions are based upon BMP, BTR or MT-LB chassis. The BTR and MT-LB based units are generally bigger for the reason that they have dedicated antitank units because of the BTRs and MT-LBs smaller firepower.

\section{IFVs and APCs}

The BTR-80 is widely used by both warring parties in the Russo-Ukraine war. The BTR-80 is part of the long evolution of the Russian Armoured Personnel Carriers (APC) and represents the technological standards of the late 1980s. Its light armour can protect its crew (driver, gunner, commander) and the mounted infantry (up to 8 soldiers) from artillery fragments and small arms fire. Its main armament is the $14.5 \mathrm{~mm}$ KPVT heavy machine gun and the coaxial 7.62mm PKT machine gun. Although the Russian Armed Forces use the BTR-82/A (equipped with a 30mm autocannon), there is no evidence of using this type of vehicle, so I will focus on the BTR-80.

The advantages of the BTR-80 is its low profile (it is only $2.35 \mathrm{~m}$ high) and its high speed. The disadvantages are numerous. Its armour cannot protect the crew and the mounted infantry even from armour-piercing shells fired from $7.62 \mathrm{~mm}$ machine guns to the top of the vehicle. Furthermore, it has literally no protection against higher calibre heavy machine guns and antitank weapons. The BTR-80 has very limited night fighting capabilities. The turret is not stabilised, so it can fire effectively only from standing position or from short stops, conducting movement. A further disadvantage is that the terrain can easily hamper the freedom of movement. A younger tree line or a very muddy road makes it impossible to pass for the BTR-80, therefore, the high speed of the vehicle can be exploited only on good quality roads and large open fields. The lack of armour

$9 \quad$ Philip A Karber, 'Lessons Learnt from the Russo-Ukraine War', The Potomac Foundation, 2015, 12.

10 Grau and Bartles, The Russian Way of War, 209. 
protection and the difficulty to open the doors resulted in the method that the infantry does not climb in the vehicle, but travels on top of it. ${ }^{11}$

The BMP-2 Infantry Fighting Vehicle (IFV) is the basic IFV used by the ex-Soviet militaries. Its advantages compared to the BTR-80 are its improved armour (however, the wrecks in Eastern Ukraine show that the BMP-2 also cannot withstand the $30 \mathrm{~mm}$ cannon and the RPG) and the fact that the BMP is a tracked vehicle; therefore, it can move more easily than the BTR-80. Its main armament is the 2A24 30mm autocannon and the 9M113 Konkurs anti-armour missile. Also, it has a coaxial 7.62mm PKT machine gun. In Eastern Ukraine, both warring parties used the BMP-2 widely. It is important to note that if the BMP-2 is used by a well-trained crew, in a well-led unit, against similar level military equipment, it is still a potent IFV. ${ }^{12}$

\section{Crew-served weapons}

The military field manuals and theoretical papers often refer to the PKM and the RPG as crew-served weapons, but in the Russian system (and more importantly in combat) these weapons are handled by one soldier.

Therefore, in this part, I will only write about the 9P115 Metis antitank wire-guided missile launcher that fires the 9M115 Metis or 9M131 Metis-M missile. It can effectively destroy armoured targets (even main battle tanks) up to 1,500 metres. It carries a HEAT warhead, and only the most modern active self-defence equipment (which cannot be found in Eastern Ukraine) can protect the armoured assets against this weapon. The Metis can be found in the motorised rifle companies' and/or battalions' antitank platoon. ${ }^{13}$

\section{Small arms}

The venerable AK-74 is available in large quantities and will be standard for years to come. The AK-74 is a line descendant of the AK-47 and the AKM, however, the AK-74 joined the "small bullet trend" introduced by the M-14 in Vietnam. The 5.45 x 39mm cartridge fires a lightweight, high-velocity bullet up to 500 metres of effective range. It is not particularly accurate, but in the nature of this conflict (overwhelming fire before manoeuvre) it is not a big problem.

The RPK squad automatic weapon is the basic small arms, around which the infantry squads' fire system is built. It is basically an AK-47 with a longer and of course more durable barrel. It has an effective range of up to 800 metres and is reliable and easy to use. The main role of this weapon is to provide suppressive fire during the squad manoeuvre. Sooner or later this will be replaced by the PKP machine gun.

11 The description of the BTR-80 is made by the author based on his extensive experiences with this APC.

12 See https://fas.org/man/dod-101/sys/land/row/bmp-2.htm

13 Rosoboronexport, Russian Defence Export, Metis M-1. Online: http://roe.ru/eng/catalog/land-forces/missilesystems-multiple-rocket-launchers-mrl-atgm-systems-and-field-artillery-guns/metis-m1/ 
The PKM medium machine gun is the best medium machine gun in the world. It is very accurate up to 600 metres but has a powerful suppressive effect up to 1,000 metres. It is easy to use, very reliable, and last but not least the lightest medium machine gun infantry can have. The PKM is a very effective machine gun and widely used by both sides in the Russo-Ukraine War.

The RPG-7V is the most widely used anti-armour weapon in the world. Its ruggedness, simplicity, low cost and effectiveness have kept it in the Russian motorised rifle squad since 1961. It has a HEAT, tandem HEAT, fragmentation and thermobaric rocket with an effective range of 200 metres. The RPGs are widely used in Eastern Ukraine by both sides and they pose a large threat to BTRs and BMPs. ${ }^{14}$

\section{The way the BTGs fight}

Since the Russians use a much different military decision-making process (which I will describe in the subsequent parts of my study) than used in the West, applying the Western concept of Warfighting Functions (WFFs) to their tactics and operations should be done with great care. In practice, the Russians do not discuss or even have a concept of WFF (Movement and Manoeuvre, Fires, Intelligence, Sustainment, Mission Command, Protection) as distinct elements assigned to various members of the staff. Instead, the WFFs are always discussed in aggregate. As the commander is much more involved with the mechanics of planning, he is also responsible for the coordination of the WFFs essential for the execution of the mission. ${ }^{15}$

This is the reason why I have mixed the order of the WFF elements, starting with the more important. Furthermore, I have found that some characteristics of the BTGs fit in more than one WFF, so I have discussed them in the view of multiple WFFs.

\section{Mission command and decision-making}

Problems with command and control and suitable employment of attached units are subjects that are not highlighted in open Russian military discussions.

In the NATO system, if at lower echelons, Mission Command is more of a science than art; at higher levels, it is more of an art than science and this situation is even more so in the Russian system. The science of combat involves the commander picking the best option for accomplishing the mission and adjusting the variables needed. This process is assisted by rigid tactics and predictability. Commanders pick from a "menu" of known tactics. Although this would irk a U.S. (or similarly NATO) commander, Russian commanders are comfortable with this system because, although tactics are simple, albeit in aggregate,

14 The characterisation of the AK, PKM and RPG is made by the author based on his extensive experiences with these weapons.

15 Roger N McDermott and Charles K Bartles, 'The Russian Military Decision-Making Process and Automated Command and Control’, GIDSresearch no 2 (2020), 34. 
when multiple simple tactics are combined to accomplish a given task, a given manoeuvre could appear complex. Since these manoeuvres are not developed "on-the-fly" and are instead a collection of simple tasks, the planning process is much less involved than an equivalent manoeuvre by a U.S. unit.

As I mentioned above, using conscripts led by professional NCOs and officers harmonises with the above described Russian way of military decision-making. Conscripts can be trained to conduct only some very specific tasks. The squads and platoons consist of soldiers trained like this who are comfortable with conducting only some specific tasks that they are highly trained for. Of course, this means limited tactical flexibility, because a given unit can conduct only some specific tasks at a high level, other combat activities may not be conducted at a professional level. Although since the Russian military had the initiative in Easter Ukraine (except the summer of 2014) it was not a major problem, they experienced only the advantages of this "specialisation".

The contemporary manoeuvre battlefield has a great tempo, very little reaction time in a large battlespace, and high lethality. Once the battle is joined, the tempo and sudden changes on the battlefield leave little time to produce and disseminate intelligence and formulate plans and orders. Cyberattacks and electronic warfare threaten communication.

In the NATO-style MDMP system, the staff develops COAs regarding the commanders' intent and the current situation. And after consideration (the length of which depends on the time available) the commander decides what to do. The Russian system is different, the Russian commander is much more involved in the process. In the Russian system, it is the commander who develops the course of action, not the staff. Upon receipt of orders, the Russian commander makes his decision based on his orders and understanding of the operational environment and passes his decision to his staff and subordinate commanders for implementation. His decision has at least three elements, the concept of the fight, tactical missions and coordination. The commander outlines his plan on a battle map, selecting from a collection of well-rehearsed tactical battle drills. The Russian tactical staff is normally smaller than its Western counterparts; this is due not only to the more active role of the commander but also due to the emphasis on battle drills and repetition, which lessens planning duties. ${ }^{16}$

All in all, we can see, that the Russian military decision-making process is faster than the NATO-style. It is because it puts a much more emphasis on using drills and wellrehearsed tactics, and also during planning, the staff uses a wide scale of mathematical nomograms. This makes the process faster but it also has a great risk of being easily predictable. It is a question that can be decided only at the field of battle: which warring party will achieve success, the one that is faster or the one that is more detailed and sophisticated.

$16 \quad$ Ibid. 31. 


\section{Movement and manoeuvre}

The nature of warfare has radically changed since the end of the Cold War. Modern combat will involve greater depth, fluidity and mobility than in the past. Continuous defensive lines of shoulder-to-shoulder will give way to open flanks, meeting engagements and the struggle to gain important areas that will undermine the tactical stability of the defensive forces. ${ }^{17}$

The above-cited statement has a charming irony, hence in the Russo-Ukraine War only once happened something that supports this changing nature of warfare. The irony becomes more charming if we highlight the fact that this operation was conducted by the Ukrainians. This one occasion was the "Great Raid" conducted by a brigade-level combat team of the Ukrainian Army in the summer of 2014. Otherwise, I agree, the joint forces combat is becoming even more mobile, fluid and rapid, the first year of the war proves this statement.

In order to meet the requirements of the $21^{\text {st }}$ century's joint forces combat, the Russian BTG has to be able to perform troop movements and conduct combat manoeuvres in a very fast way. According to all relevant Western, Russian (and even Hungarian) field manuals, the troop movement is always a planned, organised and continuously led activity. The goal of the troop movements is to move a unit from its departing positions to a desired area. The unit must arrive at an exact time and in full combat strength. To achieve these goals, the units conducting troop movements have to use formations and battle order.

In order to arrive at the battlefield, the Russian BTGs had to use marching formations. March can be administrative and combat marches. I do not intend to deal with the moving of the BTGs from their garrisons to Eastern Ukraine. My focus is on the troop movements conducted West of the Russian-Ukrainian border. These marches were all combat marches. In order to successfully conduct a combat march, the marching unit has to utilise camouflage at a very high level. Camouflage has to be active, realistic and permanent. The camouflage was not only a need of the battlefield, but it was an intention of the high politics, to cover the presence of Russian forces as long as possible. To avoid early detection by Ukrainian ISR elements, the Russian BTGs had to employ strict radio silence. In nowadays conflicts' saturated electronic "battleground”, the most important part of camouflage is the electronic camouflage. This not only means the above-mentioned strict radio silence, but the complete absence of using callsigns, names and keywords, which can be a betrayal. To accomplish this, the Russians deployed a wide scale of EW assets.

The other key element to the movement's success is to utilise the correct battle order. The main part of the battle order is the unit's formation. The ground units' standard march formation is the column. The marching column is organised so that the battalions may move directly into combat if needed. It means that the order of the column must assure the ability to quickly shift to combat formation from march formation. These key features of combat marches can be found in the Western and Russian manuals also. This is natural

17 U.S. Army FM 7-100.2, Opposing Force Tactics, 4-3. 
because at this level the rules of combat compel both sides to meet largely the same requirements. ${ }^{18}$

Because of that, I assume, that the fundamentals of combat marches are similar to the rules utilised by NATO armies. The Russian BTG will use recon elements not less than 24h before the arrival of the BTG. The BTG will send out a vanguard platoon and this platoon also sends a recon squad, just like the NATO armies would do. The Russian BTG also utilises screening forces at the sides of its movement corridor, also just like the NATO armies would do.

The Russians are considered to be the masters of the "maskirovka" (camouflaging troops). This remains true, hence the Ukrainian military suffered some shocking surprise attacks in the late spring and summer of 2014 (i.e. Zelenopylya rocket artillery attack). The Ukrainian military did not have evidence of Russian troops fighting in Eastern Ukraine until they met them at the battle of Ilovaysk (10 August 2014). ${ }^{19}$ This means the Russian BTGs conducted troop movements from the border to their Area of Operations at a very professional level. The complete air defence superiority largely contributed to the success of the concealment.

Manoeuvres can be conducted by fire or by troops. Manoeuvre by troops is the organised movement of troops during combat to a more advantageous position to attack or repulse the enemy. Manoeuvre makes it possible to seize and hold the initiative and prevent enemy success, and most importantly, to create a grouping of forces favourable to us. The Russo-Ukraine war is a conventional armed conflict. As it is a conventional armed conflict, it is not a surprise that most of the combat manoeuvres were conducted during offensive or defensive operations.

An attack against a defending enemy can be from positions in direct contact with the enemy or from the march. When possible, Russians prefer to attack from the march. Often the first battle will be the covering force battle, where Russian forward detachments push through light enemy screening forces and call air, missile and artillery strikes on them. Air assaults may supplement forward detachment effort to cut off enemy units in the covering force area. ${ }^{20}$ In Eastern Ukraine, the Russian Air Force was not used for obvious political reasons. But the battle of the covering and screening forces came more into focus. Mainly when the pro-Russian forces gained territory, it was a constant struggle of the screening forces. In the battle of Ilovaysk and the battle of Debaltseve, the proRussian forces steadily tried to infiltrate the Ukrainian defences and when they have found the weak points, the manoeuvre forces conducted the main attack. ${ }^{21}$ However, in Eastern Ukraine, the recon tasks and the probing attacks were conducted by separatist militias and only the main attack was conducted by regular Russian forces.

Since the beginning of the conflict, the extended use of indirect fires could be seen. In this part, I only mention that the support from the local civilians and the widespread use of

18 U.S. Army FM 3-21.1, SBCT Infantry Rifle Company, 3-9.

19 Radio Free Europe/Radio Liberty, 'British Investigators: More Evidence Found of Russian Role in Donbass', 19 August 2019.

20 Boston and Massicot, The Russian Way of Warfare, 9.

21 Niklas Masuhr, 'Lessons of the War in Ukraine for Western Military Strategy', CSS Analyses in Security Policy no 242 (2019), 2. 
infiltration tactics made it extremely easy to locate Ukrainian forces and to control indirect fires against them (for the use of indirect fires see sub-section Fires).

There are five basic types of combat manoeuvres. Envelopment, encirclement, breakthrough, frontal attack, evasive movement. At the tactical level, these manoeuvres are largely the same as in the NATO manuals. The main difference is the speed and the fires employed during the manoeuvre. Although these specific features of Russian military manoeuvres can be observed only during military exercises, hence in Eastern Ukraine the Russians were keen to avoid exposing their troops and putting them into the first line, mainly for political reasons (avoid providing evidence of Russian Army presence). There were only limited occasions when Russian BTGs conducted combat manoeuvres against the Ukrainian forces (see sub-section Examples from the battlefield).

All in all, it can be determined, that the Russian BTGs can conduct the same types of manoeuvres, known in the NATO, but the main difference is the speed (the main reason is the high mobility of IFVs) and the extensive use of fires, supporting the movement.

\section{Intelligence}

Almost everyone has an image of the professional and highly effective Soviet KGB agents. By today this is long gone. The KGB's successor intelligence agencies became more effective and they use the latest technology to gather the information needed.

In the Russian system, the term intelligence can mean intelligence or reconnaissance or a combination of both. In a military context, especially at a tactical level, the term usually refers to reconnaissance activities. At the battalion level, the officer in charge of the intelligence staff section is also in charge of reconnaissance, but since at the battalion level most manoeuvre units do not have dedicated reconnaissance assets, regular units from the battalion are assigned for this purpose on an ad hoc basis. The main difference between the Russian BTG's intelligence officer and the NATO-style S2 officer in charge is that the NATO S2 officer in charge does not directly command any reconnaissance units, but the Russian does. The implication of this systemic difference between the Russian and Western acquisition of intelligence is that Soviet/Russian reconnaissance units, such as Spetsnaz, would be normally associated with the intelligence staff, as opposed to the operations staff as in most Western armies. ${ }^{22}$ However, in the Russo-Ukraine war, the Russians avoided using the regular units for ad hoc reconnaissance missions, in order to avoid being captured by the Ukrainians.

In the Russo-Ukraine war, the main ways of gathering information were the recon tasks made by local militias, drones, electronic intelligence and recon by force manoeuvres. This conflict is the first in which the UAVs (Unmanned Aerial Vehicles) have been present on both sides in significant numbers and they can have a dramatic impact that is quite different from anything experienced in unilateral American use.

The surprising thing about the Russian use of drones is not in the mix of vehicles themselves or their unique characteristics, but rather in their ability to combine multiple

22 National Security and Defence, No. 1-2, Razumkov Centre, 2019, 40. 
sensing platforms into a real-time targeting system for massed, not precision, fire strikes. There are three critical components to the Russian method:

- the sensor platforms which are often used at multiple altitudes over the same target with complementary imaging

- a command-and-control system, which nets their input and delivers a strike order

- an on-call ground-based delivery system that can produce strikes within short order ${ }^{23}$

The wide-scale use of drones remained the main characteristic of warfare after the great battles ended. The trench warfare of the past 2-3 years resulted in the phenomenon that instead of the conventional ways of reconnaissance, the drones and the EW assets came into focus.

Russia's growing technological advances in EW will allow its forces to jam, disrupt and interfere with NATO communications, radar and other sensor systems, Unmanned Aerial Vehicles (UAVs), and other assets, thus negating advantages conferred on the Alliance by its technological edge. ${ }^{24}$ In this conflict, a large number of Russian EW systems appeared and were moved across the porous border with Ukraine, providing an opportunity to experiment with these EW systems. For example, on 13 May 2017, the OSCE Special Monitoring Mission (SMM) observed a Russian-made Orlan-10 UAV flying across the road from Makiivka (12 km northeast of Donetsk) towards Donetsk City. The frequently sighted Orlan-10 functions as part of the Leer-3 EW system. ${ }^{25} \mathrm{EW}$ was used in the Donbas conflict by all parties. On the separatist side, this covered the broad range of EW operations, from blocking mobile phone signals to targeted jamming of military communications systems and radars. EW usage in the conflict can be categorised as follows:

- EW to target Ukrainian UAS by the jamming controller or GPS signals

- ECM to disrupt electronically fused munitions ranging from artillery to mortars

- disruption of enemy communications: in some parts of the region no communications systems function

- targeting C2: Russian EW assets detect electromagnetic emissions, which can be located and targeted ${ }^{26}$

All in all, I can state, that the Russian BTGs deployed in Eastern Ukraine had a wide range of reconnaissance assets at hand, and they could gather the right information from the Ukrainian forces.

23 Karber, 'Lessons Learnt’, 14.

24 Roger N McDermott, 'Russia’s Electronic Warfare Capabilities to 2025', ICDS, September 2017, 5.

25 OSCE, 'Latest from the OSCE Special Monitoring Mission to Ukraine (SMM), based on information received as of 19:30, 14 May 2017’, Vienna, 15 May 2017.

26 McDermott, 'Russia’s Electronic Warfare', 25. 


\section{Fires}

As I mentioned above, manoeuvres can be conducted not only by troops but with fire also. For the classification of fire in the Russian System see Figure 2.

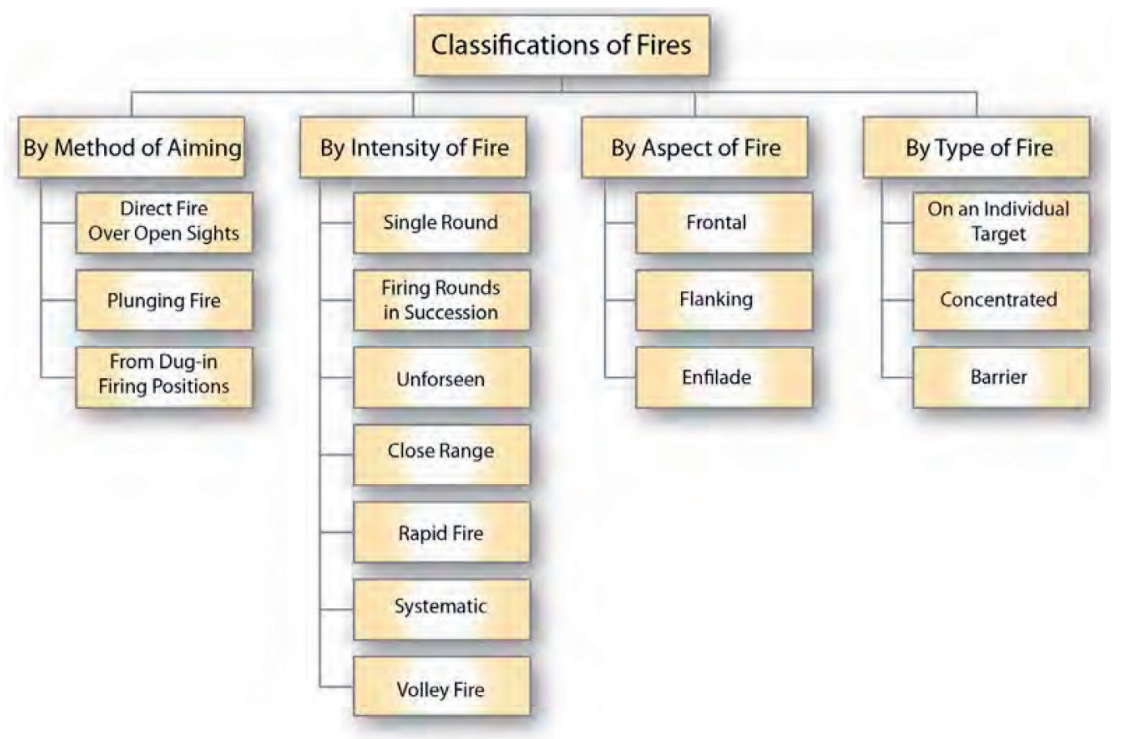

Figure 2: Russian classification of Fire Theory

Source: Grau and Bartles, The Russian Way of War, 47.

In the Russo-Ukraine war, the warring parties often preferred to fulfil their task by fire rather than manoeuvre. It has multiple reasons. In the early months of the war, the Ukrainians simply did not have enough well-trained soldiers to execute bold and effective combat manoeuvres. On the other hand, the separatists also did not have the proper training and coordination. Furthermore, the Russian "volunteers" helping their case, did not want to be caught by the Ukrainian forces.

However, in the Ukrainian 2014 summer offensive, the Ukrainians tried to recapture territory and they used bold manoeuvres. But the pro-Russian forces preferred the fires as the main tool to stop the Ukrainian advance. From the 2014 autumn pro-Russian counterattack, which led to the major battles like the Battle of Ilovaysk, the Battle of Debaltseve and the Second Battle of Donetsk Airport, the pro-Russian forces put a great emphasis on fire. Only after the wide-scale use of direct and indirect fires, executed the manoeuvres.

Conducting defensive operations, the system of fire of a battalion consists of massing the various weapons' fires by the senior commander to destroy the enemy. The system of fire must be carefully integrated with the obstacle system. It includes:

- zones of concentrated fire and lines of anti-aircraft gun fire on the approaches of the defence, in front of the forward edge of the defence, on the flanks and throughout the depth of the defence 
- anti-tank zones of fire and continuous multi-layered fire by all types of weapons before the FEBA, in the gaps, on the flanks and throughout the depth of the defence to destroy the first wave of tanks and other armoured vehicles of the enemy

- pre-prepared manoeuvres with fire

The system of fire is formed by taking into account:

- the firing capabilities of all types of weapons are involved

- their close integration

- their effect when combined with the engineering obstacles and natural barriers

Readiness of the system of fire is determined by:

- manning of the firing positions

- prepared range cards and firing data

- the presence of missiles and ammunition ${ }^{27}$

This fire system very much resembles the one we can find in the Hungarian and also some Allied countries' field manuals. This is not a surprise, hence the fundamentals of defence and fires are the same all around the world. The main difference is that during the Russo-Ukraine War, the Russian BTGs put an extraordinary great emphasis on fires. This is because - as I mentioned above - they wanted to avoid taking causalities among the regular Russian forces. This is why in many cases the pro-Russian forces used overwhelming firepower (both direct and indirect) when they spotted any signs of military activities among the Ukrainian lines.

In this part, it is unavoidable to talk about the wide use of artillery in this conflict. Data from the Ukraine conflict show that artillery is producing approximately $85 \%$ of all casualties on both sides. While the Ukrainians have generally used their artillery with considerable effectiveness in the defence, it is on the Russian side that we see new trends that are important for U.S. and NATO ground forces. The Russians put a great emphasis on MLRS area fires. The dramatic effect of these assets on the lethality of Russian indirect fire cannot be overemphasised. Furthermore, there are signs, that during some specific combat tasks (supporting infiltration, fighting in built-up areas) the pro-Russian forces used their self-propelled artillery pieces firing direct fires. In some cases, the pro-Russian forces used their 2S1 Gvozdika self-propelled howitzers as assault guns to simply blast a hole into the Ukrainian positions. ${ }^{28}$

The principles and the theories of fires are largely the same in the Russian Military than in the Western military culture. Fires, not personnel and systems, are massed to achieve the effect. Fire planning from squad to brigade designates areas of interlocking fire, massed fire, stopping fire and final protective fire (FPF). ${ }^{29}$ 


\section{Sustainment}

There are logistical and maintenance issues because of the wide variety and lifespan of the military equipment used, although the use of Armata chassis will mitigate some of them. One reform that has not been successful was the abolition of some logistics and maintenance units in favour of private contractors. BTGs are not immune to the logistics problems that still plague the Russian military, and BTG commanders still complain about them. There is also reporting that BTGs are augmented by staff at the Army Group and Military District level. Due to the Russian planning process, battalion staffs are quite small by NATO standards. This augmented staff may substitute for the lack of an on-sight higher headquarters (brigade/regiment), but these staff members might also be liaising with the General Staff and advising the unit commander if needed. ${ }^{30}$

\section{Protection}

The protection has multiple aspects like armour, engineering works, avoiding fratricide, EW-protection, etc. The first thing that comes to mind is the misbelief that the Russians do not care about losses. It could be true in World War II but definitely was not true in this conflict. The main reason is that the Russian political leadership tried to mimic their scale of intervention in Eastern Ukraine. The best way to do this is avoid losing soldiers and equipment. In order not to lose soldiers and equipment, you have to protect them.

This is why the Russians avoided exposing their forces to the direct effect of the Ukrainians. Of course, the Cold War-era Soviet military equipment (BMP-2, BMD, T-72) did not focus on the protection, but the speed and the firepower. As a result, the Russians used a wide range of direct and indirect fires before their attacks to destroy all the assets that could hurt them. In the time of Ukrainian advance (mainly summer 2014), they carefully moved their forces out of the way of the Ukrainian attacks and they used their superior firepower and the manpower of the local separatists to stop the Ukrainian advance.

In the time of trench warfare, the warring parties constructed sophisticated trenches and fortified defensive areas. The Russians are masters of fortification and camouflage. But in order not to expose the regular Russian forces to the Ukrainians, they withdrew their BTGs from the frontline and the trenches were manned by local separatist militias. But in the era of drones and real-time satellite images, it is not enough to simply pull back the forces. The Russians introduced very effective camouflage measures to hamper Ukrainian reconnaissance, surveillance and intelligence either conventional, electronic or cyber.

However, in spite of all the precautions in a war on this scale, it is unavoidable to have losses. But in the Russo-Ukraine war, we can state that the Russian BTGs put a great emphasis on protection.

30 Ramm, 'The Ukraine Test'. 


\section{Examples from the battlefield}

In this part of the study, I will briefly introduce some battles fought in Eastern Ukraine. In these examples, I will show the characteristics of the employment of the Russian BTG.

\section{The Great Raid - failure of the Russian Mission Command System?}

According to the Russian tactics (and also practically every military's tactics since SunTze), the high ground is vital. During the Great Raid (some calls Zabrodski's Raid), on 28 July 2014, the Ukrainian forces stormed the Savur-Mohyla hill. The high ground must not be defended by putting the main forces on them. It is better to defend the approaches while dominating the ground by fire from the flank and rear. It happened like this on 28 July 2014. Hence, the Ukrainian forces successfully stormed and captured the vital hill, they came under constant rocket artillery and heavy machine gun fire, and they had to continue the advance under extremely hostile circumstances. It is only the speed and the surprise factor that helped the Ukrainians to move on. This leads us to the second example.

The Great Raid clearly surprised the pro-Russian forces. It was the longest manoeuvre in modern military history. As I mentioned above, the level of success is still disputed, but the whole performance (i.e. speed, seizing the initiative, effective mission command) of the Ukrainian forces is outstanding. It is a big question why the pro-Russian forces did not stop the manoeuvre. Some say that the higher-level Russian military decision-making has failed to produce the correct orders to the forces in the operational area. ${ }^{31}$ In my point of view, the Russian forces were not present in Eastern Ukraine in the necessary number to stop a well-led, well-equipped brigade combat team. The first clear evidence of large Russian forces present in Eastern Ukraine was to be found a month later during the Battle of Ilovaysk. ${ }^{32}$ Furthermore, the Russian intelligence early discovered that the Ukrainians did not want to recapture ground, but to liberate and withdraw border security forces trapped in their barracks and to liberate the encircled airport of Luhansk. In my opinion, these reasons (not enough forces present, plus the Ukrainians did not want to hold the ground they recaptured) led the Russians to the conclusion to let the Ukrainians move where they want, they could not seriously hamper the pro-Russian forces in their advance. That can be easily admitted if we see the subsequent battles.

\section{Zelenopillya - example of the effectiveness of Russian indirect fires}

In the summer of 2014, as the Ukrainians were successfully conducting their counteroffensive against the separatists' strongholds in the Donbas and tried to drive a wedge between the separatists and their supplier, Russia initiated a series of cross-

Fiore, 'Defeating the Russian Battalion Tactical Group', 8.

Shaun Walker and Oksana Grytsenko, 'Russian soldier: "You're better clueless because the truth is horrible”, The Guardian, 03 September 2014. 
border artillery strikes against the Ukrainian units. In the space of six weeks, the Russians launched 53 fire strikes at 40 different locations, which decimated the Ukrainian forces. For example, at Zelenopillya, in a combined MLRS fire strike that lasted no more than three minutes, two Ukrainian mechanised battalions were virtually wiped out with the combined effects of top-attack munitions and thermobaric warheads. ${ }^{33}$

\section{The Second Battle for Donetsk Airport - The way of urban warfare in Eastern Ukraine}

The international airport of Donetsk was in the centre of the operations multiple times. In late May 2014, the separatists could not take the airport from the Ukrainians. But after the pro-Russian counteroffensive, the capture of the airport became a possibility by the autumn of 2014. I will not describe the events of the battle chronologically, instead, I want to focus on the way the battle was fought.

The airport is in the northeastern part of Donetsk, and it is full of all types of buildings from little shacks to massive, multi-store concrete buildings, hence it provided a classic urban battleground. According to the fundamentals of urban combat, the attacker must have 10 times superiority in terms of combat power. Furthermore, the attacker has to apply a wide scale of fires. In this battle we could see that the pro-Russian forces used the fires extensively. On 28 September 2014, the pro-Russian forces commenced their attack after they have set artillery observation posts near the airport, so they could use MLRS fire effectively. By mid-October, the warring parties reached a stalemate, the Ukrainians did not have the manpower to counterattack, and the pro-Russian forces did not have the power to effectively continue their attack. In this case, both sides used tanks, mortars and MLRS fires to destroy the enemy's strong points. Multiple times the MLRS and self-propelled artillery pieces fired directly at their targets. The culmination of the battle was the moment when the pro-Russian forces realised that they could not capture the old terminal building by a classic infantry assault. This led them to undermine the building and simply blow it up with the Ukrainian defenders inside. ${ }^{34}$

Following the Russian forces conducting urban combat, the conclusion can be drawn that the fires - as a specific way to solve tactical tasks - came even more into focus. It is easily understandable because of two reasons. First, they have tried to avoid causalities for obvious political reasons. Second, it is clearly logical that if the attacker can use massive fires to destroy the enemy, he will use it instead of sending infantry soldiers into the chaos of close-quarter combat.

Karber, 'Lessons Learnt', 19.

34 Umer Khan, 'The Battle of Donetsk Airport (2015/16) - The Replay of Grozny with Modern Weapons’, January 2020, 4. 


\section{Summary}

In my study, I have examined the characteristics of the Russian BTG. I can state that the BTGs can be used very effectively. However, they have clear disadvantages originating mainly from the age of the equipment and logistic problems. But the extensive use of effectively organised direct and indirect fires, and the overwhelming use of modern EW assets can balance these disadvantages. In the extreme circumstances of the $21^{\text {st }}$ century's conventional warfare, the fast method of decision-making, the extensive use of fires and bold manoeuvres make the Russian Battalion Tactical Group a formidable fighting force.

\section{References}

Boston, Scott and Dara Massicot, The Russian Way of Warfare. RAND Corporation, 2017. Online: https://doi.org/10.7249/PE231

Fiore, Nicholas J, 'Defeating the Russian Battalion Tactical Group’, 2017. Online: www. benning.army.mil/armor/earmor/content/issues/2017/spring/2Fiore17.pdf

Grau, Lester W Dr and Charles K Bartles, The Russian Way of War. Fort Leavenworth: Foreign Military Studies Office, 2016.

Khan, Umer, 'The Battle of Donetsk Airport (2015/16) - The Replay of Grozny with Modern Weapons', January 2020. Online: www.researchgate.net/publication/338416636_The_ Battle_of_Donetsk_Airport_-_A_Replay_of_Grozny

Masuhr, Niklas, 'Lessons of the War in Ukraine for Western Military Strategy'. CSS Analyses in Security Policy no 242 (2019). Online: https://doi.org/10.3929/ethz-b-000335676

McDermott, Roger N, 'Russia’s Electronic Warfare Capabilities to 2025'. ICDS, September 2017. Online: https://icds.ee/wp-content/uploads/2018/ICDS_Report_Russias_Electronic_ Warfare_to_2025.pdf

McDermott, Roger N and Charles K Bartles, 'The Russian Military Decision-Making Process and Automated Command and Control'. GIDSresearch no 2 (2020).

Karber, Philip A, 'Lessons Learnt from the Russo-Ukraine War', The Potomac Foundation, 2015.

OSCE, 'Latest from the OSCE Special Monitoring Mission to Ukraine (SMM), based on information received as of 19:30, 14 May 2017’, Vienna, 15 May 2017. Online: www.osce. org/special-monitoring-mission-to-ukraine/317386

Radio Free Europe/Radio Liberty, 'British Investigators: More Evidence Found of Russian Role in Donbass’, 19 August 2019. Online: www.rferl.org/a/british-online-research-group-saysmore-evidence-found-of-russian-role-in-donbas-conflict/30116665.html

Ramm, Aleksey, 'The Ukraine Test: The New Image of Armed Forces Spoiled by French Kitchens’. Voyenno Promyshlenny Kuryer, 29 April 2015.

Takács, Márk, A kelet-ukrajnai szárazföldi hadműveleteinek bemutatása. PhD thesis, 2020.

Walker, Shaun and Oksana Grytsenko, 'Russian soldier: "You're better clueless because the truth is horrible”.' The Guardian, 03 September 2014. Online: www.theguardian.com/ world/2014/sep/03/ukraine-soldier-youre-better-clueless-because-truth-horrible-moscowilovaysk 